\section{JURNAL ABDIMAS

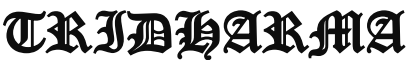

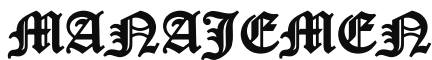

P-ISSN 2615-6849, E-ISSN 2622-3686

Jurnal ABDIMAS Vol. 1,No. 3,September 2020,Hal (63-74)

@Prodi Manajemen Fakultas Ekonomi Universitas Pamulang

Email: abdimasjurnal.unpam@gmail.com Telp: (021) 741-2566

\title{
PENINGKATAN KINERJA KADER POSYANTEK (POS PELAYANAN TEKNOLOGI TEPAT GUNA) DALAM PELAKSANAAN PROGRAM PENGELOLAAN TEKNOLOGI TEPAT GUNA (TTG)
}

\author{
Angga Pratama*, Rahmi Andini Syamsuddin, Budhi Prabowo, Eko Sudarso, \\ Lismiatun \\ Dosen Ekonomi Fakultas Ekonomi Universitas Pamulang \\ Email* : dosen02155@unpam.ac.id, dosen02062@unpam.ac.id, \\ Dosen02034@unpam.ac.id, dosen02070@unpam.ac.id \\ dosen01460@unpam.ac.id
}

\begin{abstract}
ABSTRAK
Salah satu dari tujuan Tridharma Perguruan Tinggi selain Pendidikan dan Penelitian adalah Pengabdian Kepada Masyarakat (PKM). Hal ini diatur dalam Pasal 20 dan 24 Undang-Undang. No. 20 Tahun 2003 tentang Sistem Pendidikan Nasional yang menyatakan bahwa adanya otonomi oleh Perguruan Tinggi, Penelitian Ilmiah dan Pengabdian Kepada Masyarakat. Sebagai pertanggungjawaban kami, maka dalam melaksanakan tugas tersebut telah kami susun laporan kegiatan pengabdian kepada masyarakat.

Tujuan pengabdian ini adalah agar para kader Posyantek dapat mengembangkan Pelayanan Teknologi Tepat Guna (PTTG) agar pemanfaatan PTTG ini dapat diterima oleh masyarakat dengan memberikan bimbingan, pelatihan, pendampingan yang akhirnya hasil yang diciptakan menjadi tepat guna dan dapat bersaing pada industri 4.0. Oleh karena itu pengelolaan sumber daya manusia yang ada pegawai Posyantek diperlukan peningkatan kompetensi agar pemanfaatan Teknologi Tepat Guna (TTG) dapat dipahami dengan baik dan pengetahuan akan persaingan di industri 4.0 dapat dijawab dengan efektif dan efisien.

Kesimpulan dari pengabdian ini adalah masih ada beberapa peserta yaitu para kader posyantek yang masih belum paham mengenai bagaimana meningkatkan kinerja agar dapat memberikan pelayanan yang lebih maksimal kepada masyarakat sekitar. Dalam pengabdian kepada masyarakat yang dilakukan oleh dosen serta mahasiswa Fakultas Ekonomi program studi Manajemen Universitas Pamulang diharapkan mampu memberikan solusi dan pembekalan teknis manajemen dalam peningkatan kinerja para kader dari Posyantek agar mampu bersaing dalam sebuah organisasi khususnya pegawai posyantek dalam pentingnya pemanfaatan teknologi tepat guna yang ada di wilayah Kecamatan Setu Tangerang Selatan.
\end{abstract}

\section{Kata Kunci : Sumber Daya Manusia, Kinerja, Teknologi Tepat Guna}

\begin{abstract}
One of the goals of Higher Education Tridharma in addition to Education and Research is Community Service (PKM). This is regulated in Articles 20 and 24 of the Law. No. 20 of 2003 concerning the National Education System which states
\end{abstract}




\section{JURNAL ABDIMAS

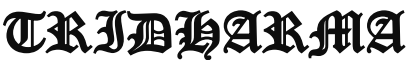

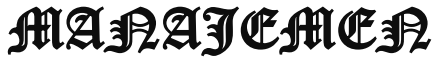

P-ISSN 2615-6849, E-ISSN 2622-3686

Jurnal ABDIMAS Vol. 1,No. 3,September 2020,Hal (63-74)

@Prodi Manajemen Fakultas Ekonomi Universitas Pamulang

Email: abdimasjurnal.unpam@gmail.com Telp: (021) 741-2566

that there is autonomy by Universities, Scientific Research and Community Service. As our responsibility, in carrying out these tasks we have prepared reports on community service activities.

The purpose of this service is that Posyantek cadres can develop Appropriate Technology Services (PTTG) so that the use of PTTG can be accepted by the community by providing guidance, training, mentoring that ultimately the results created are effective and can compete in industry 4.0. Therefore, the management of existing human resources of Posyantek employees is needed to increase competence so that the utilization of Appropriate Technology (TTG) can be understood properly and knowledge of competition in industry 4.0 can be answered effectively and efficiently.

The conclusion of this service is that there are still a number of participants, namely posyantek cadres who still do not understand how to improve performance in order to provide maximum service to the surrounding community. In community service conducted by lecturers and students of the Faculty of Economics, Pamulang University Management study program is expected to be able to provide management solutions and technical assistance in improving the performance of cadres from Posyantek to be able to compete in an organization, especially Posyantek employees in the importance of utilizing appropriate technology in South Tangerang Setu District area

\section{Keywords : Human Resources, Performance, Appropriate Technology}

\section{PENDAHULUAN}

Pembangunan merupakan suatu proses terencana guna menciptakan suatu perubahan kearah yang lebih baik dengan cepat, serta dapat memberikan berbagai macam perubahan kemajuan dalam segala bidang aspek bagi masyarakat (Priatama, 2013). Riyadi dalam (Mardikanto \& Soebiato, 2013), juga mendefinisikan pembangunan yaitu merupakan usaha atau proses perubahan, untuk tercapainya suatu tingkat kesejahteraan dan mutu hidup kelompok masyarakat atau individu didalamnya yang berkeinginan serta melaksanakan pembangunan. Pembangunan yang dimaksud yaitu pembangunan secara menyeluruh baik dari segi sosial, ekonomi, politik, keamanan dan pertahanan.
Pembangunan tidak hanya membantu memenuhi sarana dalam bentuk nyata seperti bangunan, jembatan, jalan ataupun bantuan sesaat yang diberikan pada masyarakat. Pembangunaan hendaknya juga memperhatikan kualitas sumber daya manusianya, dengan meningkatkan kualitas sumber daya manusia (SDM) untuk menjadi mandiri dengan keterampilan yang dimiliki, secara tidak langsung akan membantu mereka keluar dari jerat kemiskinan (Anwas, 2014). Perbaikan kualitas masyarakat dapat dilakukan dengan cara pemberdayaan pada masyarakat, dengan memberikan pengetahuan dan pelatihan agar mereka dapat mengembangkan diri.

Pembangunan merupakan suatu proses terencana guna menciptakan 


\section{JURNAL ABDIMAS

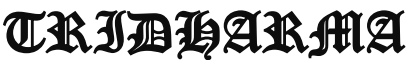

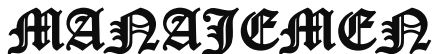

P-ISSN 2615-6849, E-ISSN 2622-3686

Jurnal ABDIMAS Vol. 1,No. 3,September 2020,Hal (63-74)

@Prodi Manajemen Fakultas Ekonomi Universitas Pamulang

Email: abdimasjurnal.unpam@gmail.com Telp: (021) 741-2566 suatu perubahan kearah yang lebih baik dengan cepat, serta dapat memberikan berbagai macam perubahan kemajuan dalam segala bidang aspek bagi masyarakat (Priatama, 2013). Riyadi dalam (Mardikanto \& Soebiato, 2013), juga mendefinisikan pembangunan yaitu merupakan usaha atau proses perubahan, untuk tercapainya suatu tingkat kesejahteraan dan mutu hidup kelompok masyarakat atau individu didalamnya yang berkeinginan serta melaksanakan pembangunan. Pembangunan yang dimaksud yaitu pembangunan secara menyeluruh baik dari segi sosial, ekonomi, politik, keamanan dan pertahanan.

Pembangunan tidak hanya membantu memenuhi sarana dalam bentuk nyata seperti bangunan, jembatan, jalan ataupun bantuan sesaat yang diberikan pada masyarakat. Pembangunaan hendaknya juga memperhatikan kualitas sumber daya manusianya, dengan meningkatkan kualitas sumber daya manusia (SDM) untuk menjadi mandiri dengan keterampilan yang dimiliki, secara tidak langsung akan membantu mereka keluar dari jerat kemiskinan (Anwas, 2014). Maka faktor utama dari kemiskinan juga terletak pada kualitas SDM suatu daerah, yang mana menjadi fokus perhatian penelitian ini. Perbaikan kualitas masyarakat dapat dilakukan dengan cara pemberdayaan pada masyarakat, dengan memberikan pengetahuan dan pelatihan agar mereka dapat mengembangkan diri. Pemberdayaan merupakan upaya yang bisa dilakukan untuk memfasilitasi masyarakat lokal dalam mengelola sumberdaya yang dimilik. Selain itu pemberdayaan juga merupakan suatu upaya mendorong masyarakat untuk mampu menjadi sosok utama dalam memanfaatkan lingkungannya guna mencapai suatu keberlanjutan untuk jangka panjang (Priatama, 2013).Seperti yang diungkapkan Santoso (2016) bahwa, pemberdayaan dengan kualitas masyarakatnya yang mandiri bisa menjadi sumbangan dalam kemajuan pembangunan nasional.

Pengenalan teknologi menjadi penting dalam upaya peningkatan pelaksanaan pemberdayaan masyarakat yang ditujukan kepada para masyarakat yang masih tradisional. Untuk itu perlu solusi yang tepat yang dapat digunakan dalam pengelolaan SDA yang ada Teknologi Tepat Guna yang selanjutnya disebut TTG adalah teknologi yang sesuai dengan kebutuhan masyarakat, dapat menjawab permasalahan masyarakat, tidak merusak lingkungan, dapat dimanfaatkan dan dipelihara oleh masyarakat secara mudah, serta menghasilkan nilai tambah dari aspek ekonomi dan aspek lingkungan.

Teknologi tepat guna sangat berperan dalam kehidupan manusia saat ini, dimana pemanfaatan sumbersumber daya yang ada dapat dikelola dengan baik dan efisien. Sehingga masyarakat dapat mengidentifikasi sedini mungkin masalah-masalah yang dihadapi dalamkehidupan sehari-hari, baik itu pemerintah, pengusahan, perguruan tinggi, petani, home industri dan lain sebagainya. Sehingga pada tahun 1998 pemerintah mendirikan Pos Pelayanan Teknologi Pedesaan (Posyantekdes) melalui menteri dalam negeri. Dalam perjalanan Posyantekdes hingga tahun 2010 melalui instruksi tersebut diperkuat oleh Peraturan Menteri Dalam Negari No. 20 tahun 2010 tentang pemberdayaan masyarakat melalui pengerlolan Teknologi Tepat Guna (TTG) agar terjadi efisiensi, 


\section{JURNAL ABDIMAS

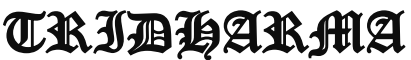

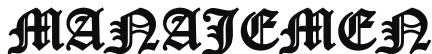

P-ISSN 2615-6849, E-ISSN 2622-3686

Jurnal ABDIMAS Vol. 1,No. 3,September 2020,Hal (63-74)

@ Prodi Manajemen Fakultas Ekonomi Universitas Pamulang

Email: abdimasjurnal.unpam@gmail.com Telp: (021) 741-2566 efektivitas, dan sinergi pembinaan antara pemerintah pusat, pemerintah daerah, dan masyarakat sehingga dari tingkat kecamatan dibentuklah Pos Pelayanan Teknologi Tepat Guna (Posyantek) yang bertugas memberikan pelayanan teknis, informasi, promosi, dan orientasi TTG kepada masyarakat. Untuk memujudkan program tersebut Posyantek tingkat Kota dan Kecamatan se Indonesia memerlukan sumber daya manusia yang berkompeten didalam bidangnya masing-masing, agar program yang sudah dicanangkan oleh kementerian dalam negeri dapat terwujud dan tepat sasaran. Sumber daya manusia yang berkompeten dapat mempercepat pertumbuhan bangsa, agar menjadi sumber daya yang maju dan produktif penduduk harus mempunyai kualitas yang memadai sehingga dapat menjadi modal pembangunan yang efektif. Masalah yang dihadapi di Indonesia saat ini adalah masih banyaknya sumber daya manusia Indonesia yang masih bekerja tidak sesuai dengan kompetensi dan bidangnya sehingga dalam menjalankan tugasnya masih jauh dari standar pekerjaannya sehingga hasil dari produktivitasnya tidak efektif dan efisien.

Dengan majunya dunia teknologi dan sistem informasi saat ini seyoganya dapat dimanfaatkan dengan baik oleh masyarakat Indonesia untuk meningkatkan daya saing terutama meningkatkan usaha mikro, usaha kecil dan menengah (UMKM). Diharapkan Melalui Posyantek Kecamatan pemanfaatan teknologi dan informasi tepat guna dapat meningkatkan kompetensi masyarkat dalam pesaingan pasar bebas dimana saat ini sudah memasuki revolusi Industri 4.0.
Sehingga kehadiran Posyantek ditingkat Kecamatan dapat membantu mempercepat peningkatan kompetensi dan pengetahuan teknologi serta informasi untuk bersaing dalam industri 4.0. Sasaran yang ingin di capai melalui program teknologi tepat guna (TTG) adalah agar teknologi yang digunakan sesuai dengan kebutuhan masyarakat, dapat menjawab permasalahan masyarakat, tidak merusak lingkungan dan dapat dimanfaatkan oleh masyarakat secara mudah serta menghasilkan nilai tambah dari aspek ekonomi dan aspek lingkungannya. Sehingga dengan bersenergi dengan Posyantek Kecamatan diharapkan masyarkat baik perseorangan, lembaga pemerintah/swasta dapat menghasilkan suatu produk yang ramah lingkungan dan tepat guna.

Penelitian yang telah dilakukan sebelumnya menunjukkan bahwa pemberadayaan masyarakat dengan TTG dapat menjaga pembangunan berkelanjutan. Penelitian dari (Rahmiyati, Andayani, \& Panjaitan, 2015) menunjukkan bahwa pemberdayaan masyarakat dengan menggunakan TTG dapat memperbaiki ekonomi serta meningkatkan produktivitas serta mutu produksi. Usaha memberdayakan masyarakat ialah langkah untuk memandirikan serta memampukan masyarakat sehingga akan muncul perubahan yang efektif. Dalam proses usaha tersebut maka diperlukan teknologi yang tepat serta relevan sesuai kebutuhan kelompok masyarakat. Ketidak tepatan teknologi yang diimplementasikan pada masyarakat akan menimbulkan masalah, karena tidak sesuai dengan kondisi lokasi pemberdayaan. Untuk keberlanjutan UMKM yang ada 


\section{JURNAL ABDIMAS

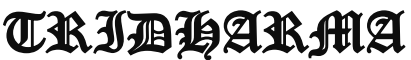

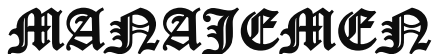

P-ISSN 2615-6849, E-ISSN 2622-3686

Jurnal ABDIMAS Vol. 1,No. 3,September 2020,Hal (63-74)

@Prodi Manajemen Fakultas Ekonomi Universitas Pamulang

Email: abdimasjurnal.unpam@gmail.com Telp: (021) 741-2566 dibutuhkan pendampingan secara teknis dan non teknis, serta keterlibatan pemerintah ialah hal mutlak yang ada dalam pemberdayaan melalui TTG. Dari penelitian diatas dapat dilihat, peran penggunaan TTG pada masyarakat, sebagai alat yang dapat menjaga pembangunan berkelanjutan dan dapat membantu dalam pembangunan 5 desa. Namun dalam penelitian terdahulu menunjukkan hasil, masih kurangnya fasilitator dan juga pendampingan dari pihak-pihak pemberdaya seperti pemerintah dan juga lembaga pemberdayaan. Dalam penelitiaan ini peneliti akan memfokuskan pada pihak pemberdaya yaitu Posyantek sebagai lembaga sosial, dalam meningkatkan kualitas masyarakat di kecamatan Wonogiri, khususnya kelompok yang telah memiliki usaha kecil. Komunikasi sangat diperlukan dalam proses pemberdayaan yang melibatkan masyarakat, penentuan strategi komunikasi pemberdaya harus disesuaikan dengan keadaan masyarakatnya. Untuk keberhasilan program dibutuhkan pendeketan secara langsung, tatap muka dengan masyarakat sasaran. Pemberdaya melakukan komunikasi secara face to face pada masyarakat agar program yang diinginkan dapat diterima melalu penjelasan yang disampaikan. Selain itu diadakan juga pertemuan atau rembug warga, untuk memberikan penjelasan secara rinci dari program yang diadakan.

Dalam perkembangannya sejak diresmikan, banyak sekali program pengembangan Posyantek seperti Lokakarya dan Training of trainer dilaksanakan, serta menetapkan Posyantek-posyantek terbaik yang sudah mapan sebagai percontohan, sekaligus diikutsertakan dalam Lomba Posyantek tingkat nasional setiap setahun sekali. Dalam hal misi sebagai pusat informasi, tentu Posyantek harus technology minded. Artinya selain Posyanteknya terkoneksi internet, pun SDM Posyantek harus "melek IT". Oleh karena itulah, operator Posyantek harus juga giat mendalami internet, social media dan blog sebagai alat dalam optimalisasi UKM di Posyantek.

Selain masalah kecakapan IT dari operator, untuk mendukung optimalisasi Posyantek ini, maka upaya dari berbagai pihak patut dilakukan. Mulai dari bagaimana pengelola dan operator Posyantek harus dapat mengoptimalkan sekretariat dan perangkat teknologi informasi yang ada untuk mengoptimalkan pelayanan kepada UKM-UKM yang tersebar di kecamatan. Hal ini bertujuan agar UKM yang ada mampu memanfaatkan teknologi tepat guna dibantu dengan Posyantek sebagai pusat diseminasi, sosialisasi dan difusi teknologi. Teknologi seperti apa yang dapat membantu masyarakat UKM meningkatkan produktivitasnya, seperti apa panduan penggunanya, hingga urun beli alat teknologi tepat guna yang bermanfaat, mungkin menjadi salah satu isu mengapa Posyantek sebagai aspek kelembagaan yang penting dalam kaitannya UKM dan Teknologi (tepat guna).

Dengan mempertimbangkan
latar belakang diatas maka kami
berinisiatif untuk membentuk
Pengabdian Kepada Masyarakat di
Posyantek Kecamatan Serpong Utara
khususnya kepada para kader posyantek
agar dapat meningkatkan kinerjanya
dalam rangka pelaksanaan program




\section{JURNAL ABDIMAS

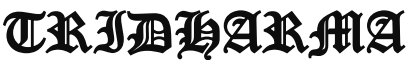

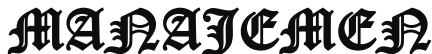

P-ISSN 2615-6849, E-ISSN 2622-3686

Jurnal ABDIMAS Vol. 1,No. 3,September 2020,Hal (63-74)

@Prodi Manajemen Fakultas Ekonomi Universitas Pamulang

Email: abdimasjurnal.unpam@ gmail.com Telp: (021) 741-2566 pengelolaan Teknologi Tepat Guna. Tujuan dari pengabdian ini adalah untuk meningkatkan kinerja para kader posyantek yang diukur dari kemampuan seluruh kader dalam mengoprasikan TTG yang dikembangkan di POSYANTEK.

\section{RUMUSAN MASALAH}

Kegiatan Pendidikan dan Pelatihan Penguatan Posyantek, bertujuan memberikan pemahaman bagi pengurus Posyantek dalam memberdayakan dan mengembangkan Posyantek di wilayahnya masingmasing, meningkatkan pengetahuan tentang peningkatan kapasitas serta ketrampilan managemen pengelolaan Posyantek, mempersiapkan pengurus posyantek agar dapat menjadi perintis dalam pengembangan dan pemanfaatan TTG. Metode pembelajaran dalam kegiatan penyelenggaraan pendidikan dan pelatihan penguatan Posyantek ini adalah, teori, tanya jawab dan diskusi. Materi yang akan disampaikan strategi membangun desa dengan tehnologi tepat guna, pedoman umum pengembangan Posyantek, penguatan pemberdayaan Posyantek

Berdasarkan latar belakang tersebut, maka permasalahan dalam pengabdian ini dapat dirumuskan sebagai berikut :

1. Masih belum tercapainya target Posyantek dalam pemberdayan masyarakat di Kecamatan Serpong Utara Tangerang Selatan

2. Masih kurang optimalnya pelayanan Posyantek dalam pemberdayaan masyarakat di Kecamatan Serpong Utara Tangerang Selatan

\section{TUJUAN PELAKSANAAN}

1. Memberikan pemahaman bagaimana pengelola dan operator Posyantek harus dapat mengoptimalkan sekretariat dan perangkat teknologi informasi yang ada untuk mengoptimalkan pelayanan kepada UKM-UKM yang tersebar di kecamatan

2. Memberikan pengetahuan mengenai teknologi seperti apa yang dapat membantu masyarakat UKM meningkatkan produktivitasnya, seperti apa panduan penggunanya, hingga urun beli alat teknologi tepat guna yang bermanfaat, mungkin menjadi salah satu isu mengapa Posyantek sebagai aspek kelembagaan yang penting dalam kaitannya UKM dan Teknologi (tepat guna).

\section{TINJAUAN PUSTAKA}

\section{Pengertian Manajemen}

Pengertian manajemen secara umum dapat disimpulkan dari beberapa definisi menurut beberapa ahli. Hal ini dikarenakan banyak versi definisi manajemen. Contohnya saja manajemen menurut seorang ahli bernama Mary Parker Follet yang mendefinisikan manajemen sebagai seni merampungkan pekerjaan melalui orang lain. Dari definisi tersebut didapati bahwa seseorang yang bertugas sebagai manajer dapat mengarahkan dan mengatur orang lain guna mencapai tujuan organisasi.

Di sisi lain, James A.F Stoner mendefinisikan manajemen sebagai proses pengorganisasian, perencanaan dan penggunaan SDM supaya mencapai tujuan organisai yang sudah ditetapkan.

Secara umum, pengertian manajemen merupakan suatu seni dalam ilmu dan pengorganisasian seperti menyusun perencanaan, 


\section{JURNAL ABDIMAS

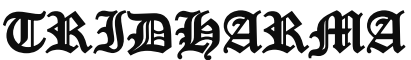

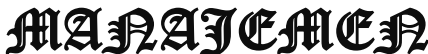

P-ISSN 2615-6849, E-ISSN 2622-3686

Jurnal ABDIMAS Vol. 1,No. 3,September 2020,Hal (63-74)

@ Prodi Manajemen Fakultas Ekonomi Universitas Pamulang

Email: abdimasjurnal.unpam@gmail.com Telp: (021) 741-2566 membangun organisai dan pengorganisasiannya, pergerakan serta pengendalian atau pengawasan. Bisa juga diartikan bahwa manajemen merupakan suatu ilmu pengetahuan yang sistematis agar dapat memahami mengapa dan bagaimana manusia saling bekerja sama agar dapat menghasilkan sesuatu yag bermanfaat bagi orang lain maupun golongan tertentu dn masyarakat luas.

Secara etimologis, pengertian manajemen merupakan seni untuk melaksanakan dan mengatur. Manajemen juga dapat dilihat sebagai ilmu yang mengajarkan proses mendapatkan tujuan dalam organisai, sebagai usaha bersama dengan beberapa orang dalam organisasi tersebut. Sehingga, ada orang yang merumuskan dan melaksanakan tindakan manajemen yang disebut dengan manajer.

\section{Fungsi Manajemen}

Pada dasarnya, fungsi manajemen dibagi menjai tiga, yaitu :

a. Perencanaan (planning)

Perecanaan adalah memikirkan apa yang akan dikerjakan dengan sumber yang dimiliki. Perencanaan dilakukan untuk menentukan tujuan perusahaan secara keseluruhan dan cara terbaik untuk memenuhi tujuan itu. Manajer mengevaluasi berbagai rencana alternative sebelum mengambil tindakan dan kemudian melihat apakah rencana yang dipilih cocok dan dapat digunakan umtuk memenuhi tujuan perusahaan. Perencanaan merupakan proses terpenting dari semua fungsi manajemen karena tanpa perencanaan, fungsi-fungsi lainnya tak dapat berjalan. b. Pengorganisasian (organizing)

Pengorganisasian dilakukan dengan tujuan membagi suatu kegiatan besar menjadi kegiatan-kegiatan yang lebih kecil. Pengorganisasian mempermudah manajer dalam menentukan orang yang dibutuhkan untuk melaksanakan tugas-tugas yang telah dibagi-bagi tersebut. Pengorganisasian dapat dilakukan dengan cara menentukan tugas apa yag harus dikerjakan, siapa yang harus mengerjakan, bagaimana tugas-tugas tersebut dikelompokkan, siapa yang bertanggungjawab atas tugas tersebut, dan pada tingkatan mana keputusan harus diambil.

c. Pengarahan (directing)

Pengarahan adalah suatu tingakan untuk mengusahakan agar semua anggota kelompok berusaha agar dapat mencapai sasaran sesuai dengan perencanaan manajerial dan usaha.

Setiap perusahaan memiliki unsurunsur untuk membentuk system manajerial yang baik. Unsur-unsur inilah yang disebut unsur manajemen. Jika salah satu diantaranya tidak sempurna atau tidak ada maka akan berimbas dengan berkurangnya upaya untuk mencapai tujuan.

\section{Kinerja}

Kinerja merupakan tingkat produktivitas seorang karyawan, relative pada rekan kerjanya, pada beberapa hasil dan prilaku yang terkait dengan tugas. Kinerja dipengaruhi oleh variabel yang terkait dengan pekerjaan meliputi role-stress dan konflik kerja / non-kerja (Riani, 2013:61).

Pengertian lain mengenai kineja diungkapkan oleh As'ad (1998:47) dalam Riani (2013:61) menyatakan bahwa kinerja adalah hasil yang dicapai oleh seseorang menurut ukuran yang berlaku untuk pekerjaan yang bersangkutan.

Kinerja seseorang merupakan kombinasi dari kemampuan, usaha dan kesempatan yang dapat dinilai dari hasil 


\section{JURNAL ABDIMAS

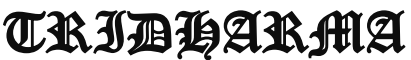

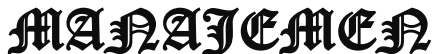

P-ISSN 2615-6849, E-ISSN 2622-3686

Jurnal ABDIMAS Vol. 1,No. 3,September 2020,Hal (63-74)

@ Prodi Manajemen Fakultas Ekonomi Universitas Pamulang

Email: abdimasjurnal.unpam@gmail.com Telp: (021) 741-2566 kerjanya (Rosidah, 2009:276). Kinerja individu dipengaruhi oleh usaha (effort), kemampuan (ability) dan situasi lingkungan (Subhki dan Jauhar, 2013:41).

Russsell dalam Rosidah (2009:276) menyatakan bahwa kinerja merupakan catatan out-come yang dihasilkan dari fungsi pegawai tertentu atau kegiatan yang dilakukan selama periode waktu tertentu. Kinerja suatu jabatan secara keseluruhan sama dengan jumlah (rata-rata) dari kinerja fungsi pegawai atau kegiatan yang dilakukan (Rosidah, 2009:276). Menurut Ivancevich M. John (2007:85) dalam Wijaya (2012:2) kinerja individu merupakan pondasi kinerja organisasi. Faktor penting dalam keberhasilan suatu organisasi adalah adanya karyawan yang mampu dan terampil serta mempunyai semangat kerja yang tinggi, sehingga dapat diharapkan suatu hasil kerja yang memuaskan. Kenyataannya tidak semua karyawan mempunyai kemampuan dan ketrampilan serta semangat kerja sesuai dengan harapan organisasi. Seorang karyawan yang mempunyai kemampuan sesuai dengan harapan organisasi, kadang-kadang tidak mempunyai semangat kerja tinggi sehingga kinerjanya tidak sesuai dengan yang diharapkan. (Sumarsono, 2004:168) dalam Wijaya (2012:2).

\section{Teknologi Tepat Guna (TTG)}

Revolusi 4.0 sama halnya pedang bermata 2 disis melukai disisi lain bermanfaat. Isu tentang keamanan data meningkat beberapa kali lipat dengan mengintegrasikan sistem baru dan semakin banyaknya akses ke sistem itu. Sebagai tambahan, pengetahuan produksi tentang kepemilikan juga menjadi masalah keamanan teknologi informasi.

Sehingga keberadaan Posyantek yang ada disetiap Kecamatan diharapkan penerapan teknologi tepat guna (TTG) dapat dimanfaatkan secara serius oleh masyarakat khususnya Posyantek sebagai penyelenggara kegiatan agar sasaran dapat tercapat secara efisien dan efektif. Kepercayaan dan stabilitas tingkat tinggi dibutuhkan untuk komunikasi fisik-siber yang sukses. Ini bisa menjadi hal yang sulit didapatkan dan dipertahankan. Mempertahankan integritas proses produksi dengan minimnya pantauan dari manusia menjadi penghalang.

Keuntungan penerapan model Industri 4.0 bisa lebih banyak daripada keprihatinan yang timbul. Ini berlaku untuk banyak fasilitas produksi. Di lingkungan kerja yang sangat berbahaya, kesehatan dan keselamatan manusia (pekerja) bisa ditingkatkan secara dramatis.

Rantai pasokan bisa lebih siap dikendalikan ketika tersedia data di setiap jenjang pemanufakturan dan proses pengantaran. Komputer yang menjadi "kontrol" bisa menghasilkan produksi yang lebih dipercaya dan konsisten. Selain itu, hasil untuk banyak bisnis bisa meningkatkan pendapatan, pangsa pasar, dan keuntungan. Peran kita kedepannya sebagai seorang farmasi, dimana sebagai seorang farmasis kita tetap harus memiliki skill, attitude, knowledge, dan tetap bisa beradaptasi dengan perubahan yang ada sekarang. Seiring berkembangnya zaman, skill yang dimiliki tentunya harus juga terus berevolusi dan bertambah seiring perubahan atau perkembangan zaman.

Setiap orang yang mengeksploitasi dan menggunakan alam adalah demi 


\section{JURNAL ABDIMAS

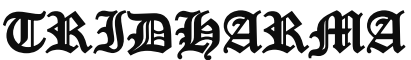

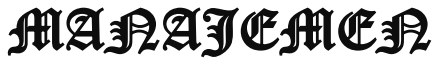

P-ISSN 2615-6849, E-ISSN 2622-3686

Jurnal ABDIMAS Vol. 1,No. 3,September 2020,Hal (63-74)

@Prodi Manajemen Fakultas Ekonomi Universitas Pamulang

Email: abdimasjurnal.unpam@gmail.com Telp: (021) 741-2566 kepentingan manusia dan juga mahluk hidup sekitarnya, seorang farmasis yang terlibat lansung dalam pembuatan obat yang memiliki limbah harus mampu membantu dala penanganan limbah dan harus sesuai prosedur yang telah ditentukan, dalam memanfaatkan alam harus memperhatikan estetika dan keindahan dan juga memanfaatkan sumber daya alam sesuai kebutuhan, penyiapan analisis pengembangan mengenai dampak lingkungan serta bentuk perilaku ramah lingkungan,

Kita dapat melihat sekarang Indonesia semakin berkembang dengan era modern sekarang kita diharapkan dapat membantu mewujudkan Indonesia sehat dengan membantu masyarakat terpencil yang tidak terjamah oleh pemerintah lewat peran kita sebagai seorang farmasis yang bergerak dibidang kesehatan dengan melakukan kegiatan social seperti pengabdian, dengan adanya peran farmasis dalam hal mewujudkan Indonesia sehat ini kita membantu masyarakat yang ketika hanya untuk berobat mereka harus ke kota dengan adanya bakti sosial ini dapat meningkatkan akses pelayanan kesehatan dengan cara terjun lansung untuk melakukan pelayanan dan kita juga dapat lebih mudah membantu dalam bidang peningkatan pengetahuan masyarakat dalam bidang kesehatan anatara lain bagaimanakah cara kita dapat mewujudkan pola hidup sehat, mengonsumsi obat secara tepat.

Indonesia sangatlah membutuhkan orang-orang yang dapat peduli dengan bangsanya sendiri, terutama pemudapemuda sebagai penggerak saat ini diharapkan dapat mewujudkan Indonesia yang lebih baik lagi terutama pada tahun 2025 dimana pada saat itu kita mendapat bonus demografis yang dimana penduduk usia produktif di Indonesia lebih besar dalam hal ini adalah para pemuda dan pemudi dengan ini kita patut mengoptimalkan kemampuan sejak dini agar siap nantinya menghadapi bonus demografis terutama para pemuda yang bergerak dibidang farmasi. Perhatian kepada masyarakat haruslah sungguh-sungguh karena dampaknya akan mempengaruhi kualitas sumber daya manusia itu sendiri.

\section{METODE PELAKSANAAN}

Metode kegiatan ini berupa pelatihan kepada kader Posyantek tentang PENINGKATAN KINERJA KADER POSYANTEK (POS PELAYANAN TEKNOLOGI TEPAT GUNA) DALAM PELAKSANAAN PROGRAM PENGELOLAAN TEKNOLOGI TEPAT GUNA (TTG) dan diharapakan dapat memberikan motivasi bagi para kader posyantek. Metode kegiatan yang digunakan adalah melalui kunjungan langsung ke Kecamatan Serpong Tangerang Selatan khususnya tempat Pos Pelayanan Teknologi Terpadu (Posyantek), dengan memberikan seminar, pelatihan dan pendampingan terhadap pegawai Posyantek yang ada dilingkungan Kecamatan Setu Tangerang Selatan.

Posyantek diharapkan menjadi bagian dari kelembagaan pelayanan bagi UKM untuk meningkatkan daya saingnya, memajukan usahanya, secara kolektif menjadi mandiri bersama. Menjadi semakin baik guna mendorong sektor ekonomi dari tingkat kecamatan, dimana terdiri dari kelurahan-kelurahan dengan berbagai potensi produksi ekonomi yang dapat menjadi motor penggerak perekonomian warga melalui UKM-UKM yang ada. Adapun tujuan dilaksanakannya kegiatan ini adalah 


\section{JURNAL ABDIMAS

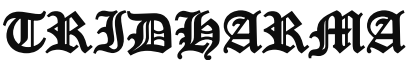

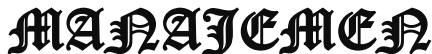

P-ISSN 2615-6849, E-ISSN 2622-3686

Jurnal ABDIMAS Vol. 1,No. 3,September 2020,Hal (63-74)

@ Prodi Manajemen Fakultas Ekonomi Universitas Pamulang

Email: abdimasjurnal.unpam@ gmail.com Telp: (021) 741-2566
Untuk menginspirasi dan memotivasi aparat dan masyarakat membentuk dan mengembangkan Pos pelayanan Teknologi (Posyantek). Sharing informasi dan pengalaman dalam membentuk dan mengembangkan Posyantek. Menyampaikan informasiinformasi tentang Teknologi Tepat Guna (TTG) kepada masyarakat melalui Posyantek. Memotivasi Penerapan TTG di masyarakat. Memberikan layanan konsultasi dan pendampingan kepada masyarakat dalam penerapan dan pemanfaatan TTG. Meningkatkan pengetahuan dan wawasan bagi aparat dan pengurus Posyantek

Dalam pelatihan ini peserta pelatihan dan training diberikan materi tentang ketrampilan dalam kecakapan IT agar dapat mendukung optimalisasi Posyantek. Dengan pelatihan dan training ini diharapakan pengurus dapat meningkatkan produktivitasnya sehingga sasaran-sasaran dari posyantek sendiri dapat tercapai.

Rencana pelaksanaan kegiatan adalah sebagai berikut.

Tempat: Aula Kantor Kecamatan Setu Tangerang Selatan

Waktu Pelaksanaan Kegiatan : 26 - 28 Juni 2020

Berikut ini adalah tahapan pelatihan yang dilakukan :

1. Tahap Persiapan

Tahap persiapan yang dilakukan meliputi :

a. Survei awal, pada tahap ini dilakukan survei di dua tempat yaitu survei ke lokasi

b. Pemantapan dan penentuan lokasi dan sasaran. Setelah survei maka ditentukan lokasi pelaksanaan dan sasaran peserta kegiatan.

c. Penyusunan bahan/materi pelatihan yang meliputi: Slide dan makalah untuk kegiatan pelatihan ilmu manajemen.

2. Tahap Pelaksanaan Pelatihan

Tahap ini akan menitikberatkan pada pemberian penjelasan mengenai bagaimana PENINGKATAN KINERJA KADER POSYANTEK (POS PELAYANAN TEKNOLOGI TEPAT GUNA) DALAM PELAKSANAAN PROGRAM PENGELOLAAN TEKNOLOGI TEPAT GUNA (TTG).

3. Tahap Pelatihan

Untuk melaksanakan kegiatan tersebut digunakan beberapa metode pelatihan, yaitu :

a. Metode Ceramah

Metode ceramah dipilih untuk memberikan penjelasan tentang ilmu manajemen khususnya mengenai pemasaran

b. Metode Tanya Jawab

Metode tanya jawab sangat penting bagi para peserta pelatihan. Metode ini memungkinkan para peserta dapat menggali pengetahuan sebanyakbanyaknya tentang PENINGKATAN KINERJA KADER POSYANTEK (POS PELAYANAN TEKNOLOGI TEPAT GUNA) DALAM PELAKSANAAN PROGRAM PENGELOLAAN TEKNOLOGI TEPAT GUNA (TTG)

c. Metode Simulasi

Metode simulasi ini diberikan kepada para peserta pelatihan dalam memberikan kesempatan untuk mempraktekkan materi yang diperoleh..

\section{HASIL DAN PEMBAHASAN}

Pengabdian Kepada Masyarakat (PKM) Universitas Pamulang dilakukan oleh dosen-dosen program studi Manajemen telah berjalan dengan lancar dan mendapat sambutan hangat 


\section{JURNAL ABDIMAS

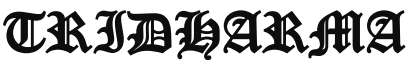

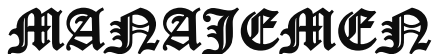

P-ISSN 2615-6849, E-ISSN 2622-3686

Jurnal ABDIMAS Vol. 1,No. 3,September 2020,Hal (63-74)

@Prodi Manajemen Fakultas Ekonomi Universitas Pamulang

Email: abdimasjurnal.unpam@gmail.com Telp: (021) 741-2566 dari para peserta kegiatan ini yaitu para para kader dari posyantek Kecamatan Serpong Utara.

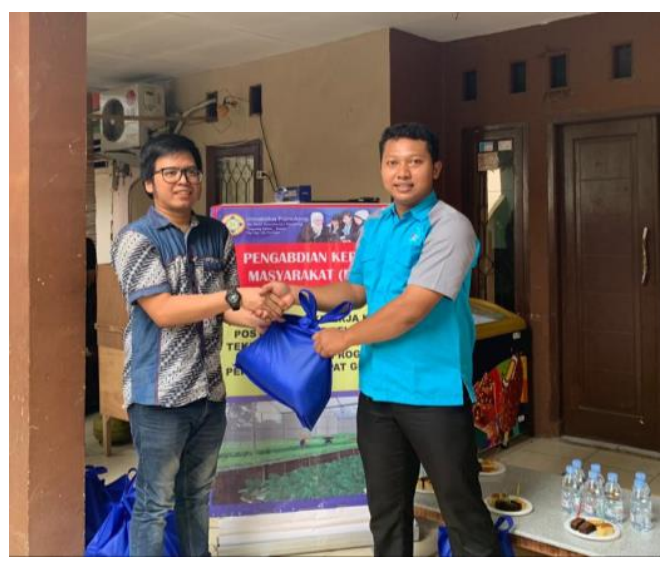

Harapan kami rengan
pengabdian ini dapat membuka wawasan masyarakat serta bertambah keilmuannya khususya para kader dari posyantek dalam meningkatkan kinerjanya. Ilmu yang diperoleh dari Pengabdian Masyarakat ini diharapkan mampu memberikan semangat baru bagi kita dalam menyampaikan materi dan motivasi serta berkontribusi bagi generasi muda, baik di lingkungan sekolah, kampus dan keluarga.

\section{KESIMPULAN DAN SARAN Kesimpulan}

Dalam pelaksanaan kami ingin mengembangkan Pelayanan Teknologi Tepat Guna (PTTG) agar pemanfaatan PTTG ini dapat diterima oleh masyarakat dengan memberikan bimbingan, pelatihan, pendampingan yang akhirnya hasil yang diciptakan menjadi tepat guna dan dapat bersaing pada industri 4.0. Oleh karena itu pengelolaan sumber daya manusia yang ada pegawai Posyantek diperlukan peningkatan kompetensi agar pemanfaatan Teknologi Tepat Guna (TTG) dapat dipahami dengan baik dan pengetahuan akan persaingan di industri
4.0 dapat dijawab dengan efektif dan efisien.

Dalam rangka meningkatkan sistem usaha pembangunan masyarakat supaya lebih produktif dan efisien, diperlukan teknologi. Pengenalan teknologi yang telah berkembang di dalam masyarakat adalah teknologi yang telah dikembangkan secara tradisional, atau yang dikenal dengan "teknologi tepat guna" atau teknologi sederhana dan proses pengenalannya banyak ditentukan oleh keadaan lingkungan dan mata pencaharian pokok masyarakat tertentu.

\section{Saran}

Guna tercapai tujuan dari Posyantek dalam menyelenggarakan teknologi tepat guna secara efektif dan efisien dalam menyongsong era industry 4.0 ada beberapa saran yang perlu diperbaiki, yakni:

1) Komunikasi

Komunikasi disini sangatlah penting karena keberhasilan dalam berkomunikasi antara penyelenggara Posyantek dengan masyarakat, maka akan memudahkan program-program posyantek dapat berjalan dengan baik.

2) Sumber daya manusia

Menambah jumlah pegawai pelaksana program TTG agar mampu menjangkau pelaksanaan program TTG sampai wilayah terpencil.

3) Struktur organisasi

Perlunya struktur organisasi yang baik agar alur kegiatan TTG dapat tepat sasaran agar Standar Operasinal Pekerjaan (SOP) dapat dijadikan acuan dalam bekerja. 


\section{JURNAL ABDIMAS

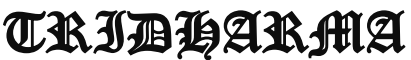

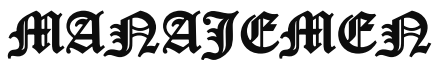

P-ISSN 2615-6849, E-ISSN 2622-3686

Jurnal ABDIMAS Vol. 1,No. 3,September 2020,Hal (63-74)

@Prodi Manajemen Fakultas Ekonomi Universitas Pamulang

Email: abdimasjurnal.unpam@ gmail.com Telp: (021) 741-2566

\section{DAFTAR PUSTAKA}

A.F. Stoner. 2006. Manajemen Sumber Daya Manusia. Jakarta: Bumi Aksara.

A.A. Anwar Prabu Mangkunegara. 2007. Manajemen Sumber Daya Manusia. Cetakan Ke Tujuh. Bandung : PT. Remaja Rosdakarya.

Dessler Gary. 2014. Manjemen Sumber Daya Manusia. Edisi Kesembilan. Jilid II. Jakarta: PT. Indeks Kelompok Gramedia.

Edi Sutrisno. 2016. Manajemen Sumber Daya Manusia. Jakarta 1: PT. Indeks Kelompok Gramedia Prenadamedia Group.

Ghozali Imam. 2006. Aplikai Analisis Multivarite dengan SPSS. Semarang : Badan Penerbit Universitas Diponegoro.

Pasaribu, V. L. D., Susanti, F., \& Hartuti, E. T. K. (2019). Memotivasi Siswa dan Siswi SMK Letris Indonesia di Dalam Menentukan Pilihan Untuk Melanjutkan Pendidikan Atau Bekerja Setelah Lulus Sekolah. Jurnal Pengabdian Dharma Laksana, 1(2), 161-172.

Pasaribu, V. L. D., Agrasadya, A., Shabrina, N., \& Krisnaldy, K. (2020). MENJADI ENTERPRENEUR MUDA YANG MEMILIKI JIWA LEADERSHIP UNTUK MENGHADAPI MASA DEPAN. Abdi Laksana, 1(1).

Pasaribu, V. L. D., Elburdah, R. P., Sudarso, E., \& Fauziah, G. (2020). PENGGUNAAN MANAJEMEN WAKTU TERHADAP PENINGKATAN PRESTASI BELAJAR DI SMP ARAISIYAH. Jurnal ABDIMAS Tri Dharma Manajemen, l(1).

Pasaribu, V. L. D., Sulaiman, S., Sutiman, S., Thaharudin, T., \& Purnomo, B. Y. (2020). PENGENALAN LETAK POSYANDU TERDEKAT DIKELURAHAN PISANGAN
DENGAN MANAJEMEN PEMASARAN REVOLUSI 4.0 UNTUK MENINGKATKAN PENGETAHUAN MASYARAKAT LETAK DAN FUNGSI POSYANDU TERDEKAT PADA KELURAHAN PISANGAN. DEDIKASI PKM, I(1), 105-110.

Pasaribu, V. L. D., Oktrima, B., Prabowo, B., Arianto, N., \& Haryoko, U. B. (2020). PROGAM PENDAMPINGAN DAN PENYELENGGARAAN

PENDIDIKAN ANAK PADA USIA DINI TERHADAP PRESTASI BELAJAR DILINGKUNGAN RT 020 RW 009. KEL GIRI PENI. KEC WATES. YOGYAKARTA. JURNAL LOKABMAS KREATIF, 1(1), 71-75

Sedarmayanti. 2012. Manajemen Sumber Daya Manusia, Reformasi Birokrasi dan Manajemen Pegawai Negeri Sipil. Bandung : PT Refika Adiatama.

Sugiyono. 2016. Metode Penelitian Pendidikan: Pendekatan Kuantitatif. Kualitatif. dan $R \& D$. Bandung: Alfabeta.

T. Hani Handoko. 2014. Manajemen Personalia dan Sumber Daya Manusia. BPFE Yogyakarta.

\section{DOKUMENTASI KEGIATAN}

\section{FOTO}

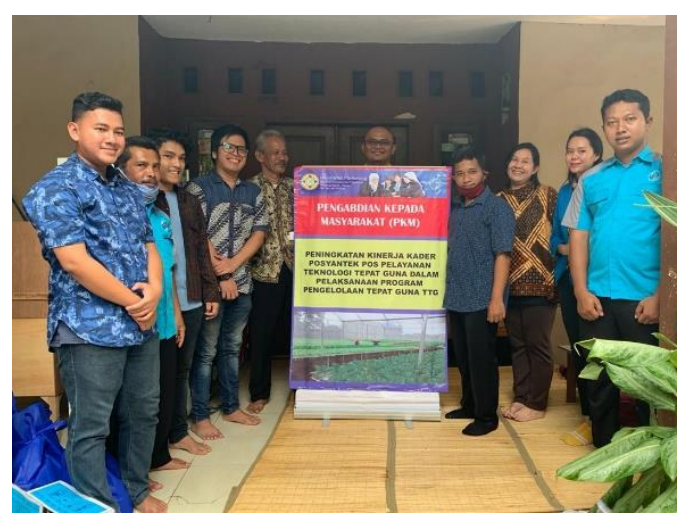

